\section{UNRECOGNISED RIGHTS, NONEXISTENT LAWS. THE INVISIBILITY OF FOREIGN TEENAGE MOTHERS: A CHALLENGE FOR SOCIAL WORK IN SPAIN}

\author{
Pablo Álvarez-Pérez \\ Universidad de Huelva \\ pablo.alvarez@dstso.uhu.es \\ Octavio Vázquez-Aguado \\ Universidad de Huelva \\ octavio@uhu.es \\ Manuela Fernández-Borrero \\ Universidad de Huelva \\ manuela.fernandez@dstso.uhu.es
}

\begin{abstract}
Citation/Cómo citar este artículo: Álvarez-Pérez, P.; VázquezAguado, O. and Fernández-Borrero, M. (2015). “Unrecognised Rights, Nonexistent Laws. The Invisibility of Foreign Teenage Mothers: A Challenge for Social Work in Spain". Arbor, 191 (771): a204. doi: http://dx.doi.org/10.3989/ arbor.2015.771n1006
\end{abstract}

Received: January 16, 2014. Accepted: July 25, 2014.

ABSTRACT: This paper addresses the reality of foreign teenage motherhood in Spain. Its importance lies not in its quantitative dimension but the implications for a growing number of girls who face motherhood at an early age. Thus, after analysing the determinants of such pregnancies, the characteristics of the phenomenon in Spain are discussed highlighting the apparent inconsistencies between this reality and the regulatory framework. In analysing the protection policies we restrict ourselves to Andalusia as a territorial demarcation. Finally, we analyse the possibilities of social work intervention aimed at supporting young mothers in order to overcome the disadvantages they face.

KEYWORDS: Foreign children; maternity; pregnancy; protection policies; legislation; social work.

\section{DERECHOS NO RECONOCIDOS, LEYES INEXISTENTES. LA \\ INVISIBILIDAD DE LAS MADRES EXTRANJERAS ADOLESCENTES: UN DESAFÍO PARA EL TRABAJO SOCIAL EN ESPAÑA}

Copyright: @ 2015 CSIC. This is an open-access article distributed under the terms of the Creative Commons Attribution-Non Commercial (by-nc) Spain 3.0 License.

RESUMEN: El presente trabajo aborda la realidad de la maternidad adolescente en menores extranjeras en España. La importancia del mismo no reside en su dimensión cuantitativa sino en las repercusiones que tiene para un número creciente de niñas que desarrollan su maternidad a edades muy tempranas. De este modo, tras analizar los factores condicionantes de este tipo de embarazos, se exponen las características del fenómeno en nuestro país poniendo de manifiesto las incongruencias existentes entre esta realidad y el marco normativo. Para el análisis de las políticas de protección nos ceñiremos a Andalucía como demarcación territorial. Finalmente, se analizan las posibilidades de intervención del Trabajo Social orientado al apoyo de las madres jóvenes con el objetivo de superar las desventajas a las que se enfrentan.

PALABRAS CLAVE: Menores extranjeras; maternidad; embarazo; políticas de protección; legislación; Trabajo Social. 


\section{INTRODUCTION}

The population in Spain has decreased by $0.2 \%$ since the beginning of 2012, representing the first population decline since 1971, the year in which the annual records were initiated (National Institute of Statistics [Instituto Nacional de Estadistica], 2013). This decline is due, among others, to a reduced immigrant presence, although it remains a fact of enormous depth. As is evident, there has been a slight decrease in the immigrant population since 2010 (National Institute of Statistics [Instituto Nacional de Estadistica], 2012, p. 3) rather than a massive return to their countries of origin. This is best seen on a larger scale. At European level, over $75 \%$ of all foreigners residing in the EU by 2010 were concentrated in five countries, among which Spain was the second largest recipient (National Institute of Statistics [Instituto Nacional de Estadistica], 2012, p. 2).

Knowing that trends in migration flows and motivations are not the same as in past decades, data on the last decade show a change in the profile of immigrants, who are not only temporal immigrants whose main purpose is to send remittances abroad, but they come with intentions to settle either for work or studies. If we also consider the influence of new technologies for the establishment and consolidation of relationships and emotional ties (Roca Girona, 2008), we find greater contact between people regardless of their nationality (Rodríguez Marcos, 2006).

Teenagers are one of the evidences of this change in profile, either because they were born in the country or because they migrated as a result of family reunification. Those who are between twelve and seventeen represent $5.52 \%$ of the total population in Spain, $87.33 \%$ of which are Spanish and $12.67 \%$ foreigners. $11.52 \%$ of girls under eighteen years in the country are foreign. These adolescents, specifically those who have given birth in Spain, are the subject of our work.

The phenomenon of teenage mothers has been addressed by the social sciences for decades (Hogan and Kitagawa, 1985; Felice et al., 1987; Luster and Mittelstaedt, 1993, Brooks-Gunn and Chase, 1994; Sánchez-Queija and Oliva, 2003; Esteve, Garcia-Roman and Permanyer, 2012). However, very few studies try to understand these mothers as children who are growing. The characteristics of adolescence have not always been taken into account as variables. In this sense, the period between 12 and 19 must be understood as a stage of major personality changes in life. This age also brings the onset of sexual attraction, which plays a key role in the phenomenon under study and explains many situations. Due to the "anatomical, psychological and social setting of early motherhood, (girls do not have) the maturity required to face this responsibility" (Catacora, 2011, p. 46).

Early motherhood is doubtlessly seen as a problem. But there is a difference between those who think that the problem is motherhood itself or and those who believe that the problem lies in the structural factors that favor this early motherhood. For the former, motherhood itself is hindering development. This has been, and remains, a view widely held by many authors (Felice et al, 1987; Osofsky, Hann and Peebles, 1993; Koniak-Griffin and Turner-Pluta, 2001) who consider early motherhood in Western society as a problem for its adverse effects at the educational level, but also regarding job placement and possible single parenthood (Panagopoulos et al., 2008, p. 265). By contrast, there are those who believe that family, social and structural factors influence or force, in a sense, early childbearing (Singh, Darroch and Frost, 2001; Kirby, Coyle and Gould, 2001; Lawlor and Shaw, 2002; Driscoll et al., 2005; Dehlendorf et al., 2010). Although it is difficult to establish what the cause-consequence relation is, we believe that environmental, structural and social factors determine this phenomenon more clearly. The World Health Organization (henceforward, WHO) shows that $90 \%$ of teenage mothers come from developing countries (WHO, 2006a, p. 8).

In the case of immigrant adolescents, there may be other factors such as the divergence in socialization between the cultural codes of their families and the codes offered by the host society (Sabatier and Berry, 2008; Huijnk, Verkuyten and Coenders, 2012; MottiStefanidi et al., 2008; Varghese and Rae, 2009; Van Oudenhoven and Ward, 2013; Portes and Rivas, 2011). These differences could influence early childbearing. A clear example within Spanish society are gypsies, who have been studied in other European countries (International Planned Parenthood Federation, 2011; UNICEF, 2011; UNFPA, 2012). In this population, the causes are associated, above all to, "discrimination and exclusion, lack of access to sexual and reproductive health, poverty and the practice of child marriage" (Williamson, 2013, p. 34) rather than to cultural issues. That is why, according to the review of data from 79 developing countries through the Demographic Health Survey (DHS) and the Multiple Indicator Cluster Survey (MICS) for the period 1998-2011, "teen birth rates are higher in rural areas, among uneducated teens, and in the poorest 20 percent of households" (Williamson, 
2013 , p. 8). This indicates that the main factor in early pregnancy is the lack of investment in the human capital of girls (International Planned Parenthood Federation, 2011). All this is very relevant in a country where there is a contrast between the reality of early motherhood and the general trend of delayed childbearing beyond the age of thirty.

\section{What are the factors that influence teenage pregnancy?}

First we stop at the environmental factors that may play a destabilizing role in the life of adolescents. It should be noted that when viewed from the opposite position, these factors become protective factors. Among such factors, Catacora (2011, p. 46) includes poverty, marginalization, level of education, family violence as a trigger for new relationships outside the nuclear family space, the onset of sexual intercourse and sexual ignorance due to social taboos. At a lower impact level, another factor is poor communication in sexual matters among young couples, which restricts the possibility of negotiating prevention and unequal gender roles (Catacora, 2011, p. 48). Rodríguez (2005, p. 141) adds new ones such as psychological, individual, family, cultural, political, institutional factors and the media. Although formerly ratified by other authors, Santos et al. (2011, p. 878) highlight immigration as a factor to be taken into account, since it might be further affected by other factors cited due to its higher vulnerability. Also Bennetta et al. (2013, p. 462) conducted a longitudinal study to demonstrate the association between low literacy in seventh grade girls with the desire to have children in their teens. This factor, although related to the educational level, goes further in trying to establish a predictive model through illiteracy. The socioeconomic status is a factor highlighted by all authors (Catacora, 2011; Rodríguez, 2005; Panagopoulos et al., 2008; WHO, 2006a; Lundstrom and Andersson, 2012). Finally, and due to its incidence in the Spanish society, we want to highlight some factors associated with Hispanic culture. The results of several studies suggest that some elements of that culture might motivate women to become mothers at an early age (Unger, Molina and Teran, 2000, p. 209). These elements are related to familism (family as a source of support, belonging, and identity), Marianism (which emphasizes the role of wife and mother as the main female roles) and sexism (father as provider for the family) (Nóblega, 2009, p. 34).

In contrast with environmental factors, some protective factors are: guaranteed access to quality education, a stable socio-economic situation, high levels of social inclusion and family support and understanding. Also we would like to highlight the following: the importance of the bonds of attachment and affection offered by parents during childhood, which are the basis for future emotional relationships (Catacora, 2011, p. 47); the self-esteem and sense of responsibility of children to prevent pregnancy (AlSahab et al., 2012, p. 229); a sufficiently developed welfare state that protects and guarantees the rights of minors (Lundström and Andersson, 2012, p. 719); and finally, the ongoing work in schools and increased compulsory public education as the guarantor of positive youth outcomes (Hill and Jepsen, 2007, p. 601). We also want to mention the process of acculturation, as some authors advocate it as a protective factor. Reynoso, Felice and Shragg (1993) conclude that acculturation is an important factor for women to be "better" mothers. Although they do not make it explicit, this idea is implicit in their comments referring that Mexican mothers adapted to American culture have higher educational and career aspirations and take into account the possibility of single parenthood. Meanwhile, a more recent study concluded that acculturation has a positive effect on Hispanic female fertility and also suggests that teenage motherhood would descend by improving the socioeconomic status of Hispanic girls (Dehlendorf et al., 2010, p. 194).

To address this reality, what exists worldwide, but especially in Europe and in most developed countries, is a preventive strategy that focuses on problem avoidance. Although we agree that this is not the best of situations and that almost all teenage childbearing is associated with many risk factors, if all efforts are focused solely on prevention, we would have, on the one hand, a reduction of unwanted pregnancy rates (thanks to the resources invested in affective-sexual education, contraceptive methods, and, ultimately, the termination of pregnancy). On the other hand, this would also imply the vulnerability of the population group that escaped preventive mechanisms and decide free or under coercion, to carry the pregnancy to term. These girls are unprotected since resources are not intended to address their needs, and they are insufficient and inadequately adapted (Williamson, 2013, p. 37). And there are many cases. According to the WHO, one in ten births in the world comes from mothers between 15 and 19 years (WHO, 2006a).

Virtually all European countries have reduced birth rates for this age group (National Institute of Statistics [Instituto Nacional de Estadistica], 2013; Santos et al., 2011; Al-Sahab, 2012; Lundstrom and Andersson, 
2012; Panagopoulos et al., 2008). The most frequent justification is the implementation of family planning strategies: emotional-sexual education, contraceptive use and abortion.

But the World Health Organization does not stop at the preventive phase. It urges countries to recognize the rights of those teenagers who become mothers. It recognizes the right of mothers to a just care before, during and after childbirth, including a requirement that girls return to school and enjoy a full social inclusion (WHO, 2006a, p. 7). And adolescents should know what the impact of marriage and early pregnancy is; those who get pregnant should have the right to access health services that are appropriate to their particular state, which should give them special rights (WHO, 2006a, p. 6), a fact that was confirmed in the Committee on the Rights of the Child in 2003.

This declaration of intent has not been launched by almost any country (Human Rights Council, 2012; Williamson, 2013, p. 81). The WHO document highlights the failure of medical services to reach the needs of pregnant adolescents (WHO, 2006a, p. 17), and explains that this "delay in seeking help" is due to factors such as lack of knowledge, poverty, lack of power to make decisions, lack of money and even cultural factors such as the preconceived idea of disease (WHO, 2002), but it is also related to the lack of interest/resources by health services.

\section{A SOCIODEMOGRAPHIC AND LEGISLATIVE REVIEW OF THE PHENOMENON OF FOREIGN TEENAGE MOTHERS IN SPAIN}

The next section will be developed through a dual perspective: the statistics of the phenomenon in Spain, and the Spanish and regional legislation circumscribed to the Andalusian case.

For the first, we have used microdata files of birth registration in Spain from the National Institute of Statistics on the Natural Population Movement. The analysis period chosen was 2000-2011.

To stay exclusively with cases of births to mothers under 18 , a selection was made according to the mother's age up to 17 , with a resulting sample of 47,426 cases. The final sample after data cleansing of lost cases, elimination of the inconsistencies found in fields such as nationality of the father, and selection of exclusively foreign women, was 13,153 cases.

Finally, for the legislative analysis, a brief review of both national and regional legislations with a brief look at the international conventions ratified by Spain. The regional analysis is due to the fact that autonomous communities are responsible for health and hygiene issues, as reported in art. 148.1.21 of the Spanish Constitution.

\section{Statistical reality in Spain}

We want to emphasize that the importance of the phenomenon under study is not due to its statistical reach, since only part of that $0.85 \%$ representing the total births to teenage mothers in Spain has been selected, but rather to its social and legal implications as there are significant differences in the fertility rate by nationality, as we can see in Table 1.

The European benchmark statistics (National Institute of Statistics [Instituto Nacional de Estadistica], 2013; Santos et al., 2011; Lundstrom and Andersson, 2012) do not consider as a factor either the legal is-

Table 1. Teenage Fertility rate in Spain (Spanish / Foreign)

\begin{tabular}{|c|c|c|c|c|c|c|c|c|c|c|}
\hline & 2011 & 2010 & 2009 & 2008 & 2007 & 2006 & 2005 & 2004 & 2003 & 2002 \\
\hline \multicolumn{11}{|c|}{15 y. o. or younger } \\
\hline Spanish & 1.9 & 1.82 & 2.01 & 2.4 & 2.14 & 2.21 & 2.09 & 2.07 & 2.17 & 1.98 \\
\hline Foreign & 8.78 & 7.69 & 8.66 & 10.85 & 11.77 & 10.59 & 12.59 & 9.38 & 14.4 & 12.15 \\
\hline \multicolumn{11}{|l|}{16 y. 0.} \\
\hline Spanish & 3.53 & 3.8 & 4.15 & 4.28 & 4.7 & 4.55 & 4.1 & 4.08 & 4.07 & 4.2 \\
\hline Foreign & 11.8 & 12.48 & 16.56 & 21.06 & 18.39 & 20.42 & 19.82 & 20.19 & 20.38 & 24.32 \\
\hline \multicolumn{11}{|l|}{17 y. 0.} \\
\hline Spanish & 6.52 & 7.22 & 7.49 & 8.3 & 8.81 & 8.23 & 7.96 & 7.73 & 7.44 & 7.46 \\
\hline Foreign & 22.9 & 23.67 & 31.15 & 35.82 & 39.43 & 36.17 & 35.68 & 36.79 & 39.01 & 41.09 \\
\hline
\end{tabular}

Source: National Institute of Statistics [Instituto Nacional de Estadistica]. 
sues that may be associated with the reality of early motherhood, or the process of development and growth in children. They stop almost exclusively on age, but analyzed from approaches such as educational attainment or access to the labor market as if they were the only backbone of a much more complex reality. In general, these statistics show mothers under twenty. If this were our field of research, adding up to 19 years would render the percentage of the total amount increasing it from $0.85 \%$ to $2.74 \%$, and if we include age 20 , it would rise to $4.13 \%$. Obviously the sample would have a much greater statistical weight, but we believe that it would lose its relevance and explanatory power as it is a phenomenon with legal, political and economic implications of some magnitude (see Figure 1).

For the period selected (2000-2011) there were a total of 5,534,534 births in Spain, of which 4,455,698 $(80.5 \%)$ were to Spanish couples and 1,078,836 (19.5\%) have at least one foreign parent. The total count of births to minors in Spain for the period 2000-2011 is 47,426 cases, representing $0.85 \%$ of the total. Our analysis focuses exclusively on cases of foreign mothers, who are 13,153 (27.73\% of the minors). These births are, by $59.9 \%$ in same-nationality foreign couples and have followed the general trend of births recorded in Spain: there is a continuous growth until 2008, at which time it decreases and stabilizes after 2010.
The ten most representative nationalities of the mother are: Ecuador, Romania, Spain, Morocco, Colombia, Bolivia, Dominican Republic, Bulgaria, Portugal and Brazil. All combined represent $88.3 \%$ of the sample. The trend on the nationalities of the father is almost equal to that of the mother. Thus we have Latin American majority, followed by European countries. The ranking is in descending order: Ecuador, Romania, Morocco, Spain, Colombia, Bolivia, Dominican Republic, Bulgaria, Portugal and Peru.

The general tendency of fathers to be older than mothers is also true for couples of minors, although it is somewhat more pronounced in the case of Moroccan females, who compared to the rest, join older fathers the most. The average age of fathers is 23; for mothers, it is 16; and for married females, it is 15 years. This trend of hypergamy because of age is associated with differences in level of education (Esteve, Garcia-Roman and Permanyer, 2012), but recent studies show that the biologist theory of hypergamy by age to ensure better offspring is incomplete by itself if it does not consider the social playback of cultural models that maintains role behaviors (Burrows, 2013, p. 203) as well as differences in opportunities for women (Dribe and Nystedt, 2013, p. 1197). In this regard, the factors that influence this phenomenon in certain nationalities should be analyzed in cultural terms (see Figure 2).

Figure 1. Percentage of Births to Foreign and Spanish Minors (2000-2011)

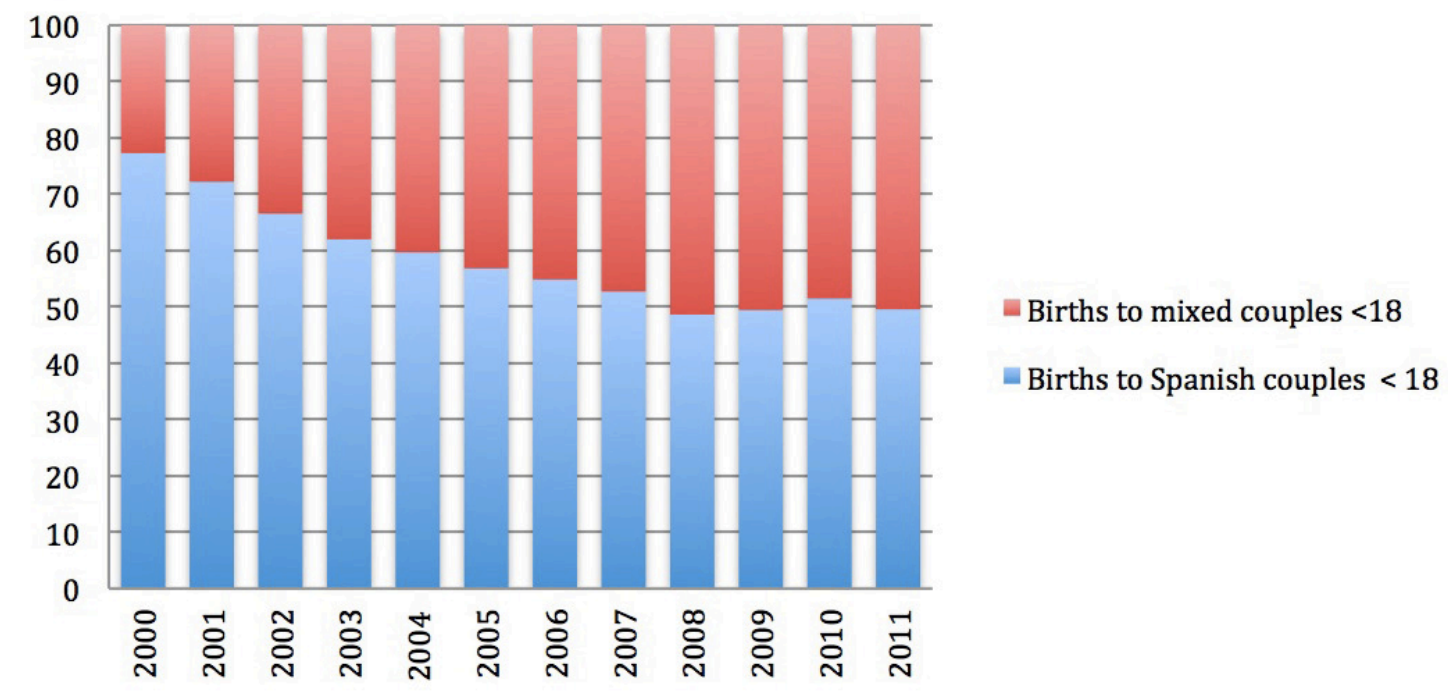

Source: National Institute of Statistics, our own. 
Figure 2. Percentage of Cases by Mother's Occupation and Type of Union

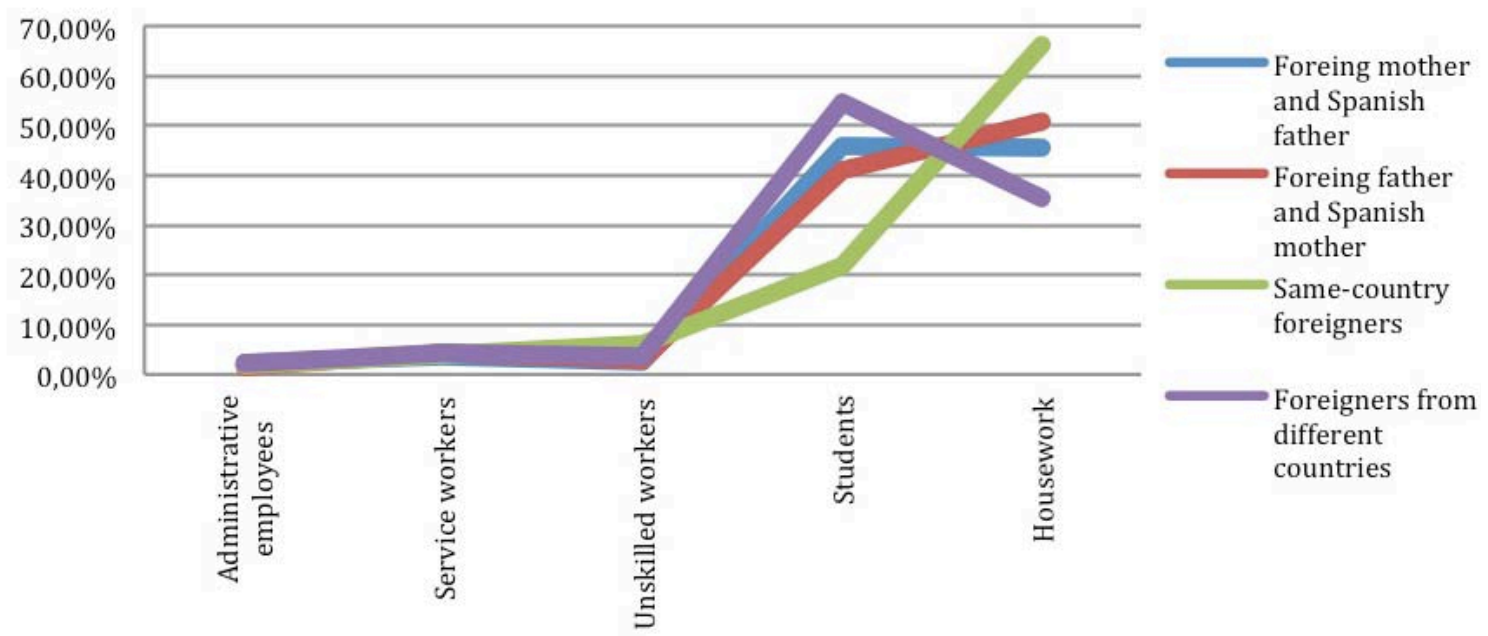

Source: National Institute of Statistics, our own.

Regarding mother's occupation, it is significant that the Spanish mothers with foreign couples are, along with foreign females who join males of their own nationality, more devoted to housework than to studies. A priori one would think that being Spaniards and having larger social and family support networks, their access to the educational system would be less difficult (Cobacho and Pons, 2006, p. 242).

Apparently it is not so. The only ones who drastically reduce the percentage in favor of students are mothers of couples from different nationalities. It is worth considering whether the elements of diversity or intercultural development of certain competencies that are present in these couples, influence the choice to continue their education or become housewives; or if there is an influence on how the role of mother is interpreted after the birth of a child according to the cultural context to which it belongs: if this can imply a return to the private sphere and the role of family care or otherwise do not interferes with personal development in the public sphere, which would strengthen their learning. The data demonstrate a return and loss of opportunities (Biddlecom et al., 2008; Lloyd, 2010; Perper, Peterson and Manlove, 2010; Loaiza and Liang, 2013; Williamson, 2013, p. 18; UNFPA, 2013).

If they are outside the education system, does it indicate that such childbearing occurs generally in an already disadvantaged and socially excluded population where the early motherhood is but one link in a chain of social exclusion?
The nuances that can be drawn from the profession when mothers are married or not, are significant. Although the majority, as expected, is not married, eight out of ten of those that are married are housewives, and less than $10 \%$ are students. By contrast, only half of the unmarried adolescents are housewives, and four out of ten go on with their studies. In addition, 75.9\% of housewives have more children in previous births in absolute value; while those engaged in administrative jobs have the least ( $2 \%$ ). This trend leads us to hypothesize about the relationship between marital status and dedication, especially in the minds of adolescents and their particular circumstances that may push them to engage in something or other. Furthermore, this leads to reflect on family models posed by these couples and the roles they assume by picking the marriage option.

It is also interesting to see how female teens are grouped with fathers according to their professions. One in four teenage housewives is attached to unskilled workers, and one in three to production workers. Also, compared with other professions, teenage housewives are more likely to be in a relationship with fathers working in the primary sector, making the $14.4 \%$. It is also observed that "unskilled" mothers join men with the same condition (73.6\%), while the trend for the rest of mothers joining unskilled workers is below $30 \%$. It is also worth noting that there is no case of unskilled mothers who join production workers. Viewed from the perspective of fathers, and taking into account the most representative professions, most fathers join housewives. Those who do so are 
the workers in the primary sector $(78.8 \%)$ and production workers (75.5\%). This highlights homogamy patterns, especially in the service sector and unskilled workers. The issue of homogamy has been previously studied in Spain (Miret, 2010). Although the general trend should be hypergamical for women, since their educational levels are quite low (Esteve, Garcia-Roman and Permanyer, 2012), this is not evident in the case of minors. The exception is housewives, who are the majority to join production workers. By contrast, men do show a trend toward hypogamy because they joint especially housewives and students.

Another issue to be considered is the existing polarity in education taking into account the nationality of the mother; that is, between those who continue their studies the most and the least. The data show a significant difference between Latin Americans and the rest. $58.6 \%$ of Dominican and half Colombian and Ecuadorian are students. All other nationalities are below $41 \%$, including Spaniards (40.9\%). An extreme case is the Moroccan, with $2.9 \%$. Bolivian and Brazilian mothers, who show the lowest Hispanic percentage, are at the same level as Spaniards. What is the influence of the social, family and friend support networks and culture of origin in choosing one way or the other?, and to what extent do the legal instruments support an itinerary that suits the vital process of adolescents? Observing and comparing the forces at play may help elucidate why some are opting for either option.

Increased dedication to housework as they grow older is related to stop being student. But quitting school and becoming housewives also have to do with the mechanisms that perpetuate the cycle of gender inequality and dependence in female adolescents with children. They have very little time to switch from the authority of their own fathers to that of their husbands or partners, to gain the responsibilities of an adult female (Williamson, 2013, p. 24), try to use their leisure time in activities appropriate to their age, take decisions about their lives and engage in remunerated work (Loaiza and Liang, 2013; Lloyd, 2010).

These cycles of inequality eventually make reconciliation impossible, if they wished to, between motherhood and school (Panday et al., 2009), although teenage mothers often leave school due to social stigma and subtle rejection of the education system (Kruger, Berthelon and Navia, 2009). Still, no matter how obvious the data, we would like to emphasize that more than half of the children had quit their studies when they were still compulsory and that few continued their training after childbearing, so that employment opportunities are minimal for them. Their employability is also conditioned by the legal requirement to be employed, which is 16 years according to Article 6 of the Spanish Statute of Workers.

Another thought about it, that still need be supported, is whether the fact of getting married involves, for minors, the de facto acceptance of traditional roles that prioritize private life to the detriment of public life. Perhaps this idea can be supported by the data from teenage mothers who engage in other occupations, and who have been married for a period under a year, especially students. Also, in relation to the option of marrying, it should be considered that Moroccan teenage mothers, who choose marriage almost entirely, are the most dedicated to being housewives.

Moreover, in relation to the professions as they compare to the continent of origin of mothers, what are the factors influencing the fact that unskilled mothers are mainly European? Is it related to the minimum legal age for employment? It is also surprising Americans show the highest rate of students. Can it be that they see the studies as a possibility of progress in the host country? The fact that they consider motherhood as natural (Nóblega, 2009, p. 34; Unger, Molina and Terán, 2000, p. 209) may also influence this behavior. If within their cultural imaginary, early motherhood is not quite stigmatized, it could be that continuing with their former life after childbearing (further study in this case) is exactly what is expected from them. By contrast, very few Africans study, so the hypothesis that there are cultural patterns related to family care or other priorities, such as work before training, arises. And with regard to Asians, they meet with the stereotype that they are more engaged than others in the service sector.

When we consider the age of the parents in those unions in which mothers are married, an inverse line is observed between these variables. The age gap between parents is much greater when they are married. Only $2 \%$ of girls are married to a younger man, while the percentage is growing steadily as parents are older: $8.78 \%$ of girls are married to men aged 18 20 years, $27.68 \%$ are married to men aged $21-25$, and $32.61 \%$ are married to men aged $26-30$. This evidence reveals important differences beyond the age contrast. The question to be asked is; why is there such a difference between parents who marry and those who do not? Again we hypothesize on cultural aspects, but also ask whether this practice is not related to patterns of discrimination and inequality. 


\section{Brief Legislative Review}

Assuming that the Spanish Constitution of 1978, Article 43.1, recognizes the right to health protection, there is a whole articulated state wide policy governing it.

To begin with, the Law 14/1986 of 25 April, on General Health sets out actions within the health system. We will only highlight some of those actions as they are related to the subject matter of this article, namely: a) education as "essential to improving individual and community health, sex education on the risks, characteristics and needs of women and men, and anti-discrimination education against women "(art. 18.1); b) "care programs for high- risk population groups and specific programs to protect against risk factors" (art. 18.5); c) programs of guidance in the field of family planning and the provision of related services (art. 18.7); and d) monitoring and improving the quality of health care at all levels (art. 18.16).

The Organic Law 3/2007 of 22 March for effective equality between women and men, amending the General Health Law (art. 6.2), introducing the equality principle. It promotes the elimination of discrimination due to the social stereotypes associated with gender and that could lead to unfair health care practices (art. 3.4). Teenage mothers carry a social stigma and the stereotypes that generate an effective discrimination, so it follows that, for an issue of equality, they should be taken into account to perform specific actions.

The Health Act also establishes the competence areas of the State and Autonomous Communities (henceforward, AC). Focusing on those that may have some impact on the phenomenon under study; we have, from the State, "the preparation of general reports on public health and health care" (Art. 40.15). In turn, each $\mathrm{AC}$ is required to prepare a health plan that "includes all sanitary measures necessary to meet the objectives of their health services." (Art. 54).

One aspect to consider in the legislation are the mechanisms for the prevention of pregnancy, especially when it becomes clear that current policies only allude to family planning, prevention of sexually transmitted diseases, and education on contraception.

In this sense, the Organic Law 2/2010 of 3 March, sexual and reproductive health and abortion establishes the right to freely chosen motherhood (art. 3.2) and non-discrimination in access to benefits and services on the grounds, among others, of age (art. 3.3). Besides, this law is committed to the development of a Strategy for Sexual and Reproductive Health (art. 11), a document that was drafted in 2011 by the Ministry of Health, Social Policy and Equality. This document prioritizes the prevention of sexually transmitted infections and contraception, how to promote health and health care, professional training, and research and innovation in this area.

But all these "declarations of intent" will remain a dead letter if they are not put into practice, and the specific actions are developed with this collective at the regional level. In regard to public support for teenage mothers, there are no specific plans or programs, but specific resources that deal with gender, risk of exclusion or other exclusive labels.

We must start with the recently published Andalusian Health Plan (Ruiz, Rabadán and Fernandez, 2013). Although within it there are six compromises with 92 objectives and 24 goals, there is no specific mention of underage mothers. It mentions implementing strategies to sexual and reproductive health throughout life (ibid., p. 22) and support measures for pregnant women in socially vulnerable situations (ibid., p. 28), but there is no reference to minors.

Moreover, we have the Order of February 21, 2013, calling for the granting of subsidies by the Andalusian Institute for Women, to non-profit entities for the care of women at risk of social exclusion. These aids have a restrictive character and preclude access to mothers who are not necessarily suffering social exclusion. Moreover, the age variable is nowhere considered, although programs for young mothers are recognized as eligible concepts. This entails a focus on the inadequacy of the proposed fund. An example is that one of the award criteria is to promote integration in the labor market, which excludes a potential group of mothers under sixteen who would still be in the age of compulsory schooling.

With regard to Decree 246/2005 of November 8, regulating the exercise of the right of minors to health care in conditions adapted to the specific needs of their age, we can say that, even if it is meant to provide a comprehensive, personalized health care, tailored to the specific needs of minors (art. 1), it only mentions gender violence and physical or psychological integrity as explicitly protected situations (art. 4.1.d).

It is also relevant to mention the Bioethics Strategy of the Andalusian Public Health System 2011-1014, which includes two objectives. The first objective is the ability to make informed and responsible decisions, although not embodied in any action beyond the review and formalization of the assessment of 
minors' rights to attention (Lorda and Esteban, 2011, p. 29). The second objective is to protect the right of citizenship, although the only activity that mentions minors focuses on training in rights and duties in relation to sexual and reproductive health focused on preventing unwanted pregnancies and sexually transmitted infections (ibid., p. 34).

As can be observed, both state and regional regulations do not expressly protect teenage mothers who have characteristics that require special attention.

In another vein, we must pay special attention to the reality of married teenage mothers because both the data and the literature review have revealed risk factors associated with this phenomenon.

Firstly, let us consider the mother's age at marriage. Knowing that the legal age to marry in Spain, currently under discussion, is 14 years (art. 48 of the Civil Code), there is a $6 \%$ (577 cases) of mothers who get married before that age. This feature raises several considerations. The first one involves making a review of international conventions/treaties that refer to the minimum age for marriage, as one-third of girls in developing countries get married before the age of eighteen (Williamson, 2013, p. 9), and one in nine, before fifteen (ibid., p. 48).

The Universal Declaration of Human Rights established the basis for the minimum age forcing states to respect the age of consent, but it does not specifically identify such age (art. 16). As a result, the Convention on Consent to Marriage, Minimum Age for Marriage and Registration of Marriages which took effect in 1964, established that member states "shall take appropriate measures (...) to determine the minimum age for marriage," (art. 2) so it is member states that ultimately determine the minimum age for marriage.

Following the International Conference on Population and Development held fourteen years ago (UNFPA, 1994), 158 countries have legislated to raise the minimum age at 18, but if laws are not enforced, they remain a dead letter (UNFPA, 2012); as we can observe today, "146 countries (...) allow girls under 18 to marry with parental consent (...), and in 52 countries, girls under 15 can marry with the consent of the parents. In contrast, 18 is the minimum age (...) for men in 180 countries. "(ibid., p. 48).

The second reflection considers the personal law applicable to matrimonial consent and capacity (art. 9.1 of the Civil Code); that is, the age requirements, physical fitness, parental consent and impediment of the relationship. Although people are entitled to apply the law of their own country, "in no case will the foreign law apply when it is contrary to public policy" (Art. 12.3 Civil Code).

Restrictions on foreign law are applicable in two situations: a) in the matrimonial capacity of the divorced spouse, as the divorce decree decides whether remarriage is possible or not, and $b$ ) when it is contrary to the public policy of the forum: for example, the marriage of a child under 12 years. This shows that $6 \%$ of mothers married before age 14 had to come to Spain after their marriage, although it was not legally recognized in Spain. In addition, there are many sentences that reveal the impossibility of registering a marriage in which one spouse is already married in another country, even by appealing to international law or personal law (AP 233/2013 of 9 May, AP 12/2004 of 14 January).

One more further point about education. Knowing that in Spain, education is compulsory until age 16 , note how this assumption is not fulfilled in teenage mothers.

If only the $39.68 \%$ of mothers within compulsory school age is pursuing their studies, there is something wrong with the system. After the appropriate review, we find that there are no control mechanisms or special aid to facilitate the continuity of these young mothers in the education system. This reality raises reflection lines, such as the explicit consideration of these girls as adults after maternity.

And we use the term "explicit" since Article 157 of the Civil Code provides that "The unemancipated minor shall exercise parental authority over their children with assistance of their parents and, in the absence of both, with the assistance of a guardian; in case of disagreement or impossibility, with the assistance of the Judge."

This legal requirement highlights a contradiction: if unemancipated teenage mothers are under the parental authority of their parents for not having full capacity to act, how can they be responsible for another human being? The answer is found in the comments to the Civil Code made by Iruzubieta Vazquez, who explains that "parental rights are an inalienable right that cannot be suppressed by law because they originate in the natural fact of procreation" (Vázquez, 2010).

These legal implications posed the subordination of civil status (maternity, in this case) to the rights and obligations inherent to personal development, or prioritization of the private sphere over the public. If so, could this law be considered discriminatory? If 
motherhood is a choice, to what extent this decision restricts rights and changes the obligations of girls, who become adults as a result of this event? This is a question that has been raised before and has highlighted the disadvantages suffered by teenage mothers (Sánchez, Hidalgo and Moreno, 2002).

\section{IMPLICATIONS AND CHALLENGES FOR SOCIAL WORK IN SPAIN IN THE LIGHT OF INTERNATIONAL EXPERIENCE}

In this section we will focus on two of the devices of Spanish protection system: community social services and primary health care. Also, experiments carried out in other countries will be very useful, especially if we want different results, but always as proposals that must be contextualized.

The Law 16/2003 of 28 May, on the cohesion and quality of the National Health System, marks the mandatory offer of social work as a core activity in its Article 12.1 on the provision of primary care. Each Autonomous Community must establish what functions are to develop. In the case of Andalusia, the Order of September 2, 1985 detailed such functions, but it was repealed by Decree 197/2007, of July 3, on the structure, organization and functioning of primary health care services to be regulated. This decree makes no mention of these functions, and considers social work as a support profession.

Health data reflecting Andalusia express the need for a greater presence of this profession. For example, within the family planning program, it reaches only $11.66 \%$ of the population at risk, including adolescents. This is linked to the issue of abortion since two thirds of those who demand this resource have not used any family planning center. In addition, over $10 \%$ of all pregnancy terminations occur in teenage mothers, which adds to the fact that $12.6 \%$ of teenagers under twenty who underwent an abortion, had already had an abortion before. Furthermore, 60\% of the 356,403 queries Social Work in Primary Care were women, which shows a feminization of care (Department of Planning and Health Innovation [Dirección General de Planificación e Innovación Sanitaria], 2011a and 2011b).

That is why the guidance and advice of the primary care teams should be one of the key elements to perform interventions at health facilities and not only from the offices of Social Work. It is a task of the social worker, to raise awareness among health professionals that the phenomenon in question must not be overlooked and that they must not respond exclu- sively to the explicit demands of adolescents, but use teenage approach to these devices to provide a comprehensive care that includes the bio-psycho-social perspective of health.

Moreover, the Regional Social Services work with a significant and increasing number of foreign nationals (Alemán, 2011, p. 836). In Andalusia, 63\% of all care provided to immigrants was given to people from South-Central America and the Maghreb, and two out of ten cases were Europeans. In addition, eight out of ten interventions for all nationalities are intended for information, guidance, assessment and resource mobilization, as well as additional resources to cover subsistence needs. The impressive thing is that one in ten users is a minor (State Secretary for Social Services and Equality [Secretaría de Estado de Servicios Sociales e lgualdad], 2011).

As shown above, there are no specific programs for pregnant teenagers. Hence, the management of this reality depends, almost exclusively, on health facilities, since they offer family planning and abortion as the only alternatives.

The main challenge of social work from these two devices of social protection involves the coordination between them so as to address the phenomenon from a holistic perspective, not only focusing on the most obvious health dimension, namely the physical one.

One strategy to generate a greater and positive impact on the psychological and social dimensions of health would be to influence the conditioning and protective factors of adolescent pregnancy as stated above. Focusing on them would, most likely, lead to a solution.

As an example, we could group these factors into four levels, which would include some aspects to take into account: a) individual: self-esteem, sense of responsibility, life planning, initiation of sexual relations and isolation in sexual matters; b) familiar: bonds of attachment and affection offered by parents in childhood, domestic violence and gender roles; c) culture: sexual ignorance because social taboos, compulsory public education, and within Hispanic culture, marianism, familism and sexism; and d) political: poverty, marginalization, welfare state, and migration. All of them are related and it could not be argued that these issues are unique to their levels. But, depending on the level, social workers have some challenges or other, although experience in other countries might provide the keys to address some of them. 
As for the individual level, we must say that having a difficult start in life that could be understood as a "failure" need not mean this situation must continue in the future (Hill and Jepsen, 2007, p. 600). In this sense, it is found that many teen mothers have a satisfactory place in the world of work above the poverty line, even with full-time jobs. Also, many continue with their education after twenty. This means that difficulties can also be a driver for change, as reflected in other studies on adolescent motherhood and resilience (Prieto, Juarez and Rutade Moreno, 2008; Oliva et al., 2008; Vázquez, Castilla and Hervas, 2007; Vera, Carbelo and Vecina, 2006).

Regarding the relationship between life project and motherhood, it is known that young people who have worked on them, channel their activities towards their achievement by postponing motherhood (Catacora, 2011, p. 33). This means that if mothers do not see education or work as real goals (because they see that they are difficult to access or do not offer a way out of their situation), being a mother could be the best decision within their limited alternatives. Working in the direction of empowerment, including self-esteem and responsibility, would increase the likelihood of success (López and Segado, 2013). An example is the Chilean experience on home visits, which included the joint development of a life project with adolescent mothers (Aracena et al., 2013, p. 159) and it was found to be effective in areas such as mental health and nutrition of the mother and the further development of language in children (ibid., p. 158). It might be interesting to design a similar program in Spain from health facilities or social services.

Moreover, it is not possible to strengthen responsibility and self-esteem in teenage mothers without considering minors themselves. In this sense, the experience of midwives in Sweden with care provision to teenage mothers (Hertfelt, von Post and Nissen, 2007, p. 269) highlights the need for a change in the mindset with which interventions are intended. The study emphasizes taking adolescents seriously for a professional care. Furthermore, this is what determines that the care bear fruit or not. The data showed that the best results are those guaranteed in aid relationships based on trust that took into account the opinion of teenagers.

At the family level, the challenge would be to create mechanisms to improve attachment bonds between parents and children, which is revealed in the Family Support Programs (Fram, 2005). These could serve as an alternative prevention and are designed to help families in difficulty. Within this reality, this study, the methodology of which is based on discussion groups, supports the idea that these programs favour domestic relations, even in cases of teenage mothers. The Chilean strategy of home visits could also work since they have a short-term positive impact as a support strategy. It would be necessary to consider how to articulate specific programs, from social services and health facilities, that help improve social and health conditions in adolescents who choose to carry the pregnancy to term. In turn, promoting cultural peace and equal treatment within families would also help reduce gender violence and role inequality (Maganto, Etxeberría and Porcel, 2010; Segado and López, 2014).

Within the cultural level we will focus mainly on education. The probability that mothers continue studying after having a child is low. In the Chilean case, this probability ranges from $80 \%$ in those with no children, to $20 \%$ in those that do have them (Rodriguez, 2005, p. 132). In America, being married increases the odds of getting pregnant and having children and can have a negative impact on educational achievement (Singh, Darroch and Frost, 2001, p. 251; Merchant, Gratton and Gutmann, 2012; Peterson et al., 2012). Also, being out of school does not mean having more opportunities to work, since most of them become housewives (ECLAC/OIJ [CEPAL (Comisión Económica para América Latina y el Caribe)], 2003 and 2004; Rodriguez, 2004). As evidenced by the statistics from the exploitation of micro-data files to Spanish level, women who marry are more likely to drop out of school, something that happens around the world. Also, contemplating marriage as a family economic survival strategy makes women occupy a secondary role dedicated almost exclusively to the care of children. The former situation could lead to the latter because if marriage involves housewifery, it is obvious that school failure is guaranteed (WHO, 2006b, p. 10). Hence strategies from social work should go through evidencing this phenomenon and proposing solutions to social exclusion, rather than mitigating its future effects. Furthermore, knowing the large percentage of Hispanic teenage mothers, it would be necessary to better understand the specific cultural factors so as to make effective intercultural interventions at the individual, family, and community levels.

Finally, on the political level, it is necessary to vindicate the change of vision of early motherhood as a source of impoverishment. Having a problematic perception of this fact unquestionably forces to take "repair" actions, which in a sense, conditions inter- 
ventions. Alternative solutions to abortion or other genital-centered options are advisable, such as emotional and sexual education. These essentially preventive measures are incomplete by themselves, as was revealed in Greece, where the Greek Family Planning Organization teaches contraception without the expected results, since rates remain high (Panagopoulos et al., 2008, p. 267). This urges us to go in search of structural answers as integral education, inclusive policies or specific programs. Although we must analyze the causes that lead minors to make this decision (which are most likely related to personal decisions, under pressure or not), it is necessary to stop associating poverty to early motherhood as if this were the only cause. This would help to find other solutions to improve their situation. (Nóblega, 2009, p. 32).

Furthermore, the World Health Organization itself encourages states to include in their national policies, actions that go beyond the law to ensure the protection of minors for premature sex, sexually transmitted infections and abortions. Among them, the WHO argues, other alternatives should be offered such as adoption and specific medical treatments. Also, policies should be aimed at reducing the social stigma, help mothers to develop a freely chosen life project and facilitate/improve access for parents to be part of the growth of children (WHO, 2006a, p. 24).

Finally we conclude with a reflection on the protection that should be offered from the rule of law to ensure the wellbeing of citizens.

The fact that Sweden has spent decades implementing effective policies on equality between men and women and to facilitate the reconciliation of work and family life (Lundström and Andersson, 2012, p. 734) has brought as a consequence, equal fertility trends between men and women, but especially, and most characteristic, between native Swedes and immigrants. The influence of a consolidated welfare state with real family policies has these effects. Moreover, this trend favors the discourse of young motherhood as the best way of life for those who have no other possibilities of progress, both educational, health or work, whether they are real or part of the cultural imaginary reference as it has been shown in other studies.

Similarly, a comparative study among five developed countries (Sweden, Canada, France, UK and USA) revealed that, comparatively, there is a very obvious disadvantage between the U.S. and the rest, as the American teenagers showed higher birth and pregnancy rates (Singh, Darroch and Frost, 2001, p. 251). The key to these differences is found in social inequality, which strongly correlates with other related sexual behavior variables, even more than ethnicity. Improving adolescent sexual behavior and reproductive strategies requires to reduce the number of young people growing up in disadvantaged conditions and to help the disadvantaged overcome the obstacles they face, and that is the responsibility of the state through its policies, which must be claimed by social work professionals.

\section{CONCLUSIONS}

The statistical data, legislative review and international studies show that the phenomenon of child motherhood is an important relevant field of study. It has also been highlighted how this social reality, multidimensional in its causes and consequences, has particular characteristics that must be addressed from many areas and not just from the individualized intervention.

In this sense, the conclusions and agreements reached by the WHO were on the line to create a legal framework and specific policies that are committed to the real welfare of mothers, special treatment within the health services by the special characteristics presented, and even adapting health services for a fair and dignified treatment.

This also includes the participation of adolescents for the implementation of programs and projects that affect them (WHO, 2006a, pp. 27-28). Right now, perhaps because they are legally considered as minors, teenage mothers are not heard as much as they should, so all strategies are designed from an adultcentered position. Future research should go in this direction.

At the legislative level, Galicia could be a good example. There, Law 5/2010, of June 23, which establishes and regulates a network of support for pregnant women, specifically refers to minor pregnant women as beneficiaries (art. 5.2). This law provides benefits to which they can accommodate, namely: education for motherhood, psychological support before and after childbirth, family intervention, support to facilitate their training at the stage of compulsory education (temporarily flexible enrollment period) and affectivesexual formation.

Moreover, given the legal loopholes in the phenomenon, the effective lack of resources that go beyond prevention and the invisibility of teenage mothers, 
social work can only work to reverse the situation. This involves networking with other agencies such as Social Services, and carrying out policies that allow confronting the phenomenon from a holistic, and not only preventive, perspective. In this sense, the areas of intervention proposed in the previous section could serve as a guideline.
Finally, we conclude that it would be beneficial to implement the experiments carried out in other countries, provided they are adapted to the local context. We must not forget that social work is also communal. For this profession to be a reference to socio-health coordination, the office work must not be separated from the reality of the neighborhood, which means going back to the origins of community social work.

\section{REFERENCES}

Alemán Bracho, C. (2011). Inmigración y Servicios Sociales. Papers, 96, 3, pp. 825-852.

Al-Sahab, B., Heifetz, M., Tamim, H., Bohr, Y. and Connolly, J. (2012). Prevalence and Characteristics of Teen Motherhood in Canada. Matern Child Health Journal, 16, pp. 228-234. http://dx.doi. org/10.1007/s10995-011-0750-8

Aracena, M., Krause, M., Pérez, J., Bedregal, P., Undurraga, C. and Alamo, N. (2013). Efectos de mediano plazo de un programa de intervención para madres adolescentes. Atención Primaria, 45, 3, pp. 157-164. http://dx.doi.org/10.1016/j. aprim.2012.09.017

Bennetta, I., Frassob, R., Bellamyd, S., Worthame, S. and Grosse, K. (2013). Pre-teen literacy and subsequent teenage childbearing in a US population. Contraception, 87, pp. 459-464. http://dx.doi.org/10.1016/j.contraception.2012.08.020

Biddlecom, A., Gregory, R., Lloyd, C. B. and Mensch, B. S. (2008). Associations between premarital sex and leaving school in four Sub-Saharan African Countries. Studies in Family Planning, 39, 4, pp. 337-350. http://dx.doi.org/10.1111/ j.1728-4465.2008.00179.x

Brooks-Gunn, J. and Chase Lansdale, P. (1994). Adolescent parenthood. En: Marc, $\mathrm{H}$. and Bornstein, $\mathrm{H}$. (eds.). Handbook of parenting: Status and social conditions of parenting (vol. 3). Nueva Jersey: Erlbaum, pp. 113-150. http://dx.doi. org/10.1207/s15327795jra0404_2/ http://dx.doi.org/10.1016/S1054139x(94)90634-3

Burrows, K. (2013). Age Preferences in Dating Advertisements by Homosexuals and Heterosexuals: From Sociobiological to Sociological Explanations. Archives of Sexual Behavior, 42, pp. 203-211. http://dx.doi.org/10.1007/ s10508-012-0031-7
Catacora, R. Y. (2011). Inicio sexual en madres adolescentes peruanas: cuando el despertar se torna difícil.COMUNI@ CCIÓN: Revista de Investigación en Comunicación y Desarrollo, 2, 2, pp. 45-55.

CEPAL (Comisión Económica para América Latina y el Caribe) (2003). Juventud e inclusión social en Iberoamérica. Santiago de Chile: Publicación de las Naciones Unidas.

CEPAL (Comisión Económica para América Latina y el Caribe) (2004). La juventud en Iberoamérica: tendencias y urgencias. Santiago de Chile: Publicación de las Naciones Unidas.

Cobacho, F. and Pons, J. (2006). Jóvenes en desventaja y cohesión social: educación y futuro para todos. Revista de Educación, 341, pp. 237-258.

Dehlendorf, C., Marchi, K., Vittinghoff, E. and Braveman, P. (2010). Sociocultural Determinants of Teenage Childbearing among Latinas in California. Matern Child Health Journal, 14, pp. 194-201. http://dx.doi. org/10.1007/s10995-009-0443-8

Dirección General de Planificación e Innovación Sanitaria. (2011a). Interrupción Voluntaria del Embarazo. Andalucía 2000-2009. Sevilla: Servicio de Información y Evaluación. Unidad Estadística, Junta de Andalucía.

Dirección General de Planificación e Innovación Sanitaria. (2011b). Memoria Estadística de la Consejería de Salud 2010. Sevilla: Servicio de Información y Evaluación. Unidad Estadística, Junta de Andalucía.

Dribe, M. and Nystedt, P. (2013). Educational Homogamy and Gender-Specific Earnings: Sweden, 1990-2009. Demography, 50, 4, pp. 1197-1216. http:// dx.doi.org/10.1007/s13524-012-0188-7

Driscoll, A. K., Sugland, B. W., Manlove, J. and Papillo, A. R. (2005). Community opportunity, perceptions of opportunity, and the odds of an adolescent birth.
American Journal of Sociology, 90, pp. 825-855.

Esteve, A., Garcia-Roman, J. and Permanyer, I. (2012). The Gender-Gap Reversal in Education and Its Effect on Union Formation: The End of Hypergamy? Population and Development, 38, 3, pp. 535-546. http://dx.doi.org/10.1111/ j.1728-4457.2012.00515.x

Felice, M., Shragg, P., James, M. and Hollingsworth, D. (1987). Psychosocial Aspects of Mexican-American, White, and Black Teenage Pregnancy. Journal of Adolescent Health Care, 8, pp. 330335. http://dx.doi.org/10.1016/01970070(87)90004-0

http://dx.doi.org/10.1016/01970070(87)90519-5

Fram, M. (2005).«It's just not all Teenage Moms»: Diversity, Support, and Relationship in Family Services. American Journal of Orthopsychiatry, 75, 4, pp. 507-517. http://dx.doi. org/10.1037/0002-9432.75.4.507

Hertfelt Wahn, E., von Post, I. and Nissen, E. (2007). A description of Swedish midwives' reflections on their experience of caring for teenage girls during pregnancy and child birth. Midwifery, 23, pp. 269-278.

Hill, L. and Jepsen, C. (2007). Positive outcomes from poor starts: Predictors of dropping back in. Economics of Education Review, 26, pp. 588-603. http://dx.doi.org/10.1016/j.econedurev.2006.04.004

Hogan, D. P., and Kitagawa, E. M. (1985). The impact of social status, family structure, and neighborhood on the fertility of Black Adolescents. American Journal of Sociology, 90, pp. 825-855. http:// dx.doi.org/10.1086/228146

Huijnk, W., Verkuyten, M. and Coenders, M. (2012). Family Life and Acculturation Attitudes: A Study among Four Immigrant Groups in the Netherlands. Journal of 
Ethnic and Migration Studies, 38, 4, pp. 555-575. http://dx.doi.org/10.1080/13 69183X.2012.659117

Human Rights Council (2012). Technical guidance on the application of a human rights-based approach to the implementation of policies and programmes to reduce preventable maternal morbidity and mortality. Report of the Office of the United Nations High Commissioner for Human Rights. Document A/HRC/21/22. Nueva York: Naciones Unidas.

Instituto Nacional de Estadística. (2012). Extranjeros en la UE y en España. Cambios poblacionales y económicos. Boletín Informativo. Madrid: Catálogo de publicaciones de la Administración General del Estado.

Instituto Nacional de Estadística. (2013). Cifras de Población a 1 de enero de 2013. Estadística de Migraciones 2012. Datos Provisionales. Notas de prensa. Madrid: Catálogo de publicaciones de la Administración General del Estado.

International Planned Parenthood Federation. (2011). Girls Decide: Choices on Sex and Pregnancy. London: IPPF.

Kirby, D., Coyle, K. and Gould, J. B. (2001). Manifestations of poverty and birthrates among young teenagers in California zip code areas. Family Planning Perspectives, 33, pp. 63-69. http://dx.doi. org/10.2307/2673751

Koniak-Griffin, D. and Turner-Pluta, C. (2001). Health risks and psychosocial outcomes of early child bearing. A review of the literature. Journal of Perinatal \& Neonatal Nursing, 15, 2, pp. 1-17. http://dx.doi.org/10.1097/00005237200109000-00002

Kruger, D., Berthelon, M. and Navia, R. (2009). Adolescent Motherhood and Secondary Schooling in Chile. IZA Discussion Paper, 4552, pp. 1-29.

Lawlor, D. and Shaw, M. (2002). Too much too young? Teenage pregnancy is not a public health problem. International Journal of Epidemiology, 31, 3, pp. 552-554. http://dx.doi.org/10.1093/ ije/31.3.552

Loaiza E. and Liang, M. (2013). Adolescent Pregnancy. A review of the evidence. New York: UNFPA

López Peláez, A. and Segado Sánchez-Cabezudo, S. (2013). Empowerment, WellBeing and the Welfare State: Family
Social Work in Spain. En: Moreno Mínguez, A. (ed.). Family Well-Being. European Perspectives. London: Springer, pp. 277-302.

Lorda, P. S. and Esteban, M. S. (coords.) (2011). Estrategia de Bioética del Sistema Sanitario Público de Andalucía: 2011 - 2014. Sevilla: Consejería de Salud, Junta de Andalucía.

Lundström, K. and Andersson, G. (2012). Labor market status, migrant status, and first childbearing in Sweden. Demographic Research, 27, 25, pp. 719-742. http://dx.doi.org/10.4054/ DemRes.2012.27.25

Luster, T. and Mittelstaedt, M. (1993). Adolescent mothers. En: Luster, T. and Okagaki, L. (eds.). Parenting: An ecological perspective. Hillsdale, NJ: Lawrence Erlbaum Associates, pp. 69-99.

Lloyd, C. B. (2010). The role of schools in promoting sexual and reproductive health among adolescents in developing countries. En: Shawn, M. (ed.).Social Determinants of Sexual and Reproductive Health. Informing future research and programme implementation. Geneva: WHO, pp. 113-132.

Maganto, J. M., Etxeberría, J. and Porcel, A. (2010). Hacia la corresponsabilidad entre los miembros de la familia como factor de conciliación. Educatio siglo XXI: Revista de la Facultad de Educación, 28, 1, pp. 69-84.

Merchant, E., Gratton, B. and Gutmann, M. (2012). A Sudden Transition: Household Changes for Middle Aged U.S. Women in the Twentieth Century. Population Research and Policy Review, 31, 5, pp. 703-726. http://dx.doi.org/10.1007/ s11113-012-9249-2

Miret, P. (2010). La similitud entre los componentes de las parejas jóvenes en España en la primera década del siglo XXI ¿Cada vez más iguales? Revista de Estudios de Juventud, 90, pp. 225-255.

Motti-Stefanidi, F., Pavlopoulos, V., Obradovic, J., Dalla, M., Takis, N., Papathanassiou, A. and Masten, A. S. (2008). Immigration as a risk factor for adolescent adaptation in Greek urban schools. European Journal of Developmental Psychology, 5, 2, pp. 235-261. http://dx.doi. org/10.1080/17405620701556417

Nóblega, M. (2009). La maternidad en la vida de las adolescentes: implicancias para la acción. Revista de Psicología, 27 1, pp. 30-54.
Oliva Delgado, A., Jiménez Morago, J., Parra Jiménez, A. and Sánchez-Queija, I. (2008). Acontecimientos vitales estresantes, resiliencia y ajuste adolescente. Revista de Psicopatología y Psicología Clínica, 13, 1, pp. 53-62. http://dx.doi.org/10.5944/ rppc.vol.13.num.1.2008.4050

Osofsky, J., Hann, D. and Peebles, C. (1993). Adolescent parenthood: Risks and opportunities for mothers and infants. En: Zeanah, C. (ed.). Handbook of infant mental health. Nueva York: Guilford Press, pp. 106-119.

Panagopoulos, P., Salakos, N., Bakalianou, K., Davou, E., lavazzo, C., Paltoglou, G. and Liapis, A. (2008). Adolescent Pregnancy in a Greek Public Hospital during a Six-year Period (2000-2005). A Retrospective Study. Journal of Pediatric \& Adolescent Gynecology, 21, pp. 265-268. http://dx.doi.org/10.1016/j. jpag.2008.05.003

Panday, S., Makiwane, M., Ranchod, C. and Letsoalo, T. (2009). Teenage Pregnancy in South Africa - With a Specific Focus on School-Going Learners. Pretoria: Child, Youth, Family and Social Development, Human Sciences Research Council. Department of Basic Education.

Perper K., Peterson, K. and Manlove, J. (2010). Diploma Attainment Among Teen Mothers. Child Trends, Fact Sheet Publication 2010-01. Washington, DC: Centers for Disease Control and Prevention.

Peterson, B., Pirritano, M., Tucker, L. and Lampic, C. (2012). Fertility awareness and parenting attitudes among American male and female undergraduate university students. Human Reproduction, 27, 5, pp. 1375-1382. http:// dx.doi.org/10.1093/humrep/des011

Portes, A. and Rivas, A. (2011). The Adaptation of Migrant Children. The Future of Children, 21, 1, pp. 219-246. http:// dx.doi.org/10.1353/foc.2011.0004

Prieto de Arancibia, E., Juárez, L. and Ruta de Moreno, M. I. (2008). Resiliencia y maternidad adolescente. En: Melillo, A., Suárez Ojeda, E. N. and Rodríguez, D. (eds.). Resiliencia y Subjetividad: Ios ciclos de la vida. Buenos Aires: PAIDOS, pp. 173-186

Reynoso, T., Felice, M. and Shragg, P. (1993). Does American Acculturation Affect Outcome of Mexican-American Teenage Pregnancy? Journal of Adolescent Health, 14, pp. 257-261. http://dx.doi. org/10.1016/1054-139X(93)90171-K 
Roca Girona, J. (dir.) (2008). Amor importado, migrantes por amor: la constitución de las parejas entre españoles y mujeres de América Latina y de Europa del Este en el marco de la transformación actual del sistema de género en España. Tarragona: Universidad Rovira i Virgili.

Rodríguez, J. (2004). La fecundidad alta en América Latina y el Caribe: un riesgo en transición. En: CEPAL/CELADE (ed.). La fecundidad en América Latina: ¿transición o revolución?, Santiago de Chile: Publicación de las Naciones Unidas, pp. 93-140.

Rodríguez, J. (2005). Reproducción en la adolescencia: el caso de Chile y sus implicaciones de política. Revista de La Cepal, 86, pp. 123-146.

Rodríguez Marcos, M. E. (2006). Familias interculturales. La construcción de la interculturalidad de lo micro social a lo macro social. Salamanca: Publicaciones Universidad Pontificia.

Ruiz, J., Rabadán, A. and Fernández, A. (dirs.) (2013). IV Plan Andaluz de Salud. Sevilla: Consejería de Igualdad, Salud y Políticas Sociales.

Sabatier, C. and Berry, J. W. (2008). The role of family acculturation, parental style, and perceived discrimination in the adaptation of second-generation immigrant youth in France and Canada. European Journal of Developmental Psychology, 5, 2, pp. 159-185. http://dx.doi. org/10.1080/17405620701608739

Sánchez, J., Hidalgo, M. V. and Moreno, M. C. (2002). Madres adultas y madres adolescentes, ¿dónde están las diferencias? Bienestar y Protección Infantil, 1 3, pp. 19-36.

Sanchez-Queija, I. and Oliva, A. (2003). Vínculos de apego con los padres y relaciones con los iguales durante la adolescencia. Revista de Psicología Social, 18, 1, pp. 71-86. http://dx.doi. org/10.1174/02134740360521796

Santos, V., Moura, M., Pinho, J., Almeida, V. and Maio, J. (2011). Características sócio-demográficas das puérperas e seguimento da gravidez. O Que Mudouem 17 Anos? Acta Medica Portuguesa, 24 6, pp. 877-884.

Segado Sánchez-Cabezudo, S. and López Peláez, A (2014). Social work with middleclass Spanish families: The challenge of the work-family conflict. International Journal of Social Welfare, 23, 1, pp. 100-111. http://dx.doi.org/10.1111/ijsw.12012
Secretaría de Estado de Servicios Sociales e Igualdad. (2011). Memoria del Sistema de Información de Usuarios de Servicios Sociales (S.I.U.S.S.). Año 2011. Madrid: Ministerio de Sanidad, Servicios Sociales e Igualdad.

Singh, S., Darroch, J. and Frost, J. (2001). Socioeconomic Disadvantage and Adolescent Women's Sexual and Reproductive Behavior: The Case of Five Developed Countries. Family Planning Perspectives, 33, 6, pp. 251-258. http:// dx.doi.org/10.2307/3030192

UNFPA (1994). Boletín de la Conferencia Internacional sobre la Población y el Desarrollo. El Cairo: UNFPA. Retrieved from: http://www.un.org/popin/icpd/ newslett/94_19/icpd9419.sp/1lead.stx. html

UNFPA (2012). Marrying Too Young. End Child Marriage. New York: UNFPA

UNFPA (2013). Messages and Preliminary Findings from the ICPD Beyond 2014 Global Review. New York: UNFPA.

Unger, J., Molina, G. and Teran, L. (2000). Perceived Consequences of Teenage Childbearing among Adolescent Girls in an Urban Sample. Journal of Adolescent Health, 26, pp. 205-212. http://dx.doi. org/10.1016/S1054-139X(99)00067-1

UNICEF. (2011). Opportunity in Crisis: Preventing HIV from Early Adolescence to Young Adulthood. New York: UNICEF.

Van Oudenhoven, J. P. and Ward, C. (2013). Fading Majority Cultures: The Implications of Transnationalism and Demographic Changes for Immigrant Acculturation. Journal of Community \& Applied Social Psychology, 23, 2, pp. 81-97. http://dx.doi.org/10.1002/ casp. 2132

Varghese, A. and Rae Jenkins, S. (2009). Parental Overprotection, Cultural Value Conflict, and Psychological Adaptation among Asian Indian Women in America. Sex Roles, 61, 3-4, pp. 235-251. http:// dx.doi.org/10.1007/s11199-009-9620-x

Vázquez, C., Castilla, C. and Hervás, G. (2007). Reacciones frente al trauma: vulnerabilidad, resistencia y crecimiento. En: Fernández-Abascal, E. (ed.). Las emociones positivas. Madrid: Pirámide, pp. 375-392.

Vázquez Iruzubieta, C. (2010). Paternidad filiación, alimentos, ausencia e incapacitación: comentarios a los artículos 108 a 214 del Código Civil. Barcelona: vLex.
Vera Poseck, B., Carbelo Baquero, B. and Vecina Jiménez, M. L. (2006). La experiencia traumática desde la psicología positiva: resiliencia y crecimiento postraumático. Papeles del Psicólogo, 27, 1, pp. 40-49.

Williamson, N. (2013). Maternidad en la niñez. Enfrentar el reto del embarazo en adolescentes. UNFPA.

World Health Organization (2002). A framework to assist countries in the development and strengthening of national and district health plans and programmes in reproductive health. Geneva: WHO Document Production Services.

World Health Organization (2006a). Pregnant Adolescents: Delivering on Global Promises of Hope. Geneva: WHO Document Production Services.

World Health Organization (2006b). Married adolescents: no place of safety. Geneva: WHO Document Production Services.

\section{Legal texts}

Audiencia Provincial de A Coruña (Sección 3a). Sentencia núm. 233/2013 de 9 mayo.

Audiencia Provincial de Guadalajara (Sección 1ra). Sentencia núm. 12/2004 de 14 enero.

Committee on the Rights of the Child. (2003). Adolescent health and development in the context of the Convention on the Rights of the Child (Thirty-third sesión, General Comment No. 4), U.N. Doc. CRC/GC/2003/4

Constitución Española. Boletín Oficial del Estado, de 29 de diciembre de 1978, núm. 311, pp. 29313-29424. Available from: https://www.boe.es/boe/ dias/1978/12/29/pdfs/A29313-29424.pdf

Decreto 197/2007, de 3 de julio, por el que se regula la estructura, organización y funcionamiento de los servicios de atención primaria de salud en el ámbito del Servicio Andaluz de Salud. Boletín Oficial de la Junta de Andalucía, de 17 de julio de 2007, núm. 140, pp. 10-18. Available from: http://www.juntadeandalucia.es/ boja/2007/140/fasciculo-1.pdf

Decreto 246/2005, de 8 de noviembre, por el que se regula el ejercicio del derecho de las personas menores de edad a recibir atención sanitaria en condiciones adaptadas a las necesidades propias de su edad y desarrollo y se crea el Con- 
sejo de Salud de las Personas Menores de Edad. Boletín Oficial de la Junta de Andalucía, de 16 de diciembre de 2005, núm. 244, pp. 14-19. Available from: http://www.juntadeandalucia.es/ boja/2005/244/boletin.244.pdf

Ley 14/1986 de 25 de abril, General de Sanidad. Boletín Oficial del Estado, de 29 de abril de 1986, núm. 102, pp. 15207-15224. Available from: https:// www.boe.es/boe/dias/1986/04/29/ pdfs/A15207-15224.pdf

Ley 16/2003 de 28 de mayo, de cohesión y calidad del Sistema Nacional de Salud. Boletín Oficial del Estado, de 29 de mayo de 2003, núm. 128, pp. 2056720588. Available from: https://www. boe.es/boe/dias/2003/05/29/pdfs/ A20567-20588.pdf

Ley $5 / 2010$, de 23 de junio, por la que se establece y regula una red de apoyo a la mujer embarazada. Boletín Oficial del Estado, de 19 de julio de 2010, núm. 174, pp. 63319-63325. Available from: http://www.boe.es/ boe/dias/2010/07/19/pdfs/BOEA-2010-11489.pdf
Ley Orgánica 2/2010, de 3 de marzo, de salud sexual y reproductiva y de la interrupción voluntaria del embarazo. Boletín Oficial del Estado, de 4 de marzo de 2010, núm. 55, pp. 21001-21014. Available from: http://www.boe.es/ boe/dias/2010/03/04/pdfs/BOEA-2010-3514.pdf

Ley Orgánica 3/2007, de 22 de marzo, para la igualdad efectiva de mujeres y hombres. Boletín Oficial del Estado, de 23 de marzo de 2007, núm. 71, pp. 12611 12645. Available from: https://www. boe.es/boe/dias/2007/03/23/pdfs/ A12611-12645.pdf

Orden de 2 de septiembre de 1985, por la que se aprueba el Reglamento General de Organización y Funcionamiento de los Centros de Atención Primaria en Andalucía. Boletín Oficial de la Junta de Andalucía, de 19 de septiembre de 1985, núm. 90, pp. 2681-2685. Available from: http://www.juntadeandalucia.es/boja/1985/90/boletin.90.pdf

Orden de 21 de febrero de 2013, por la que se convoca la concesión de subvenciones por el Instituto Andaluz de la Mujer, a en- tidades sin ánimo de lucro para la atención a mujeres en situación de riesgo de exclusión social, para el año 2013. Boletín Oficial de la Junta de Andalucía, de 25 de marzo de 2013, núm. 58, pp. 9-25. Available from: http://www.juntadeandalucia. es/boja/2013/58/BOJA13-058-00196.pdf

Organización de las Naciones Unidas. (1962) Convención sobre el consentimiento para el matrimonio, la edad mínima para contraer matrimonio y el registro de los matrimonios. Resolución de la Asamblea General, 1763 a (XVII), de 7 de noviembre de 1962. Available from: http://www2. ohchr.org/spanish/law/matrimonio.htm

Organización de las Naciones Unidas (1948). Declaración Universal de Derechos Humanos. Resolución de la Asamblea General, 217 a (III) del 10 de diciembre de 1948. Available from: http://www. un.org/es/documents/udhr/

Real Decreto de 24 de julio de 1889 por el que se publica el Código Civil. Boletín Oficial del Estado, de 25 de julio de 1889, núm. 206, pp. 249-259. Available from: https://www.boe.es/datos/pdfs/ BOE/1889/206/R00249-00312.pdf 